\title{
A brief history of the pathology of the gonads
}

\author{
Robert H Young \\ James Homer Wright Pathology Laboratories, Massachusetts General Hospital, Harvard Medical School, \\ Boston, MA, USA
}

\begin{abstract}
Our understanding of gonadal pathology has reached its current state as a result of the contributions of numerous outstanding investigators. Knowledge of testicular tumor pathology dates back to the great British workers Percival Pott and Sir Astley Cooper but the single greatest early stride was made with the description in 1906 by the French urologist Maurice Chevassu of the seminoma. The seminal 1946 paper of Nathan B Friedman and Robert A Moore, which segregated out as a distinct entity embryonal carcinoma, is, however, the foundation for the current classification of testicular tumors. In that year Pierre Masson described the distinctive neoplasm, the spermatocytic seminoma. The 1950s saw the publication of an important paper by Frank J Dixon and Dr Moore and they also wrote the first series fascicle on testicular tumors. In this same timeframe, and thereafter, Robert E Scully made significant contributions to testicular pathology, writing the first English language paper on spermatocytic seminoma, describing several subtypes of sex cord tumor, and also the distinctive lesion of intersex, the gonadoblastoma, as well as playing a major role in 1980 in formulating the current classification of premalignant lesions of the testis. The current classification of testicular tumors was arrived at in the early $1970 \mathrm{~s}$ when the World Health Organization, under the leadership of Dr FK Mostofi, who himself made notable contributions to testicular pathology, devised what is fundamentally the current classification of neoplasms of the male gonad. Although comments on ovarian pathology were made by such legendary figures of earlier times as Giovanni Battista Morgagni and Matthew Baillie, it is only in the mid to later years of the 19th century that contributions, mostly in Europe, began to move knowledge of ovarian pathology to its current state. Thomas Hodgkin, Richard Bright, and Sir James Paget all wrote extensively on ovarian neoplasms. In 1870, Heinrich Waldeyer, and later in that century, another German, Hermann Johannes Pfannenstiel wrote important papers on the surface epithelial tumors. The latter was likely the first to refer to neoplasms now known as of 'borderline malignancy' and also wrote on pseudomyxoma peritonei and other topics. Their work was followed by that of Robert Meyer who made monumental contributions to gynecological pathology, including recognizing the Brenner tumor as a distinctive neoplasm and proposing the first classification of Sertoli-Leydig cell tumors (arrhenoblastomas). He also coined the term 'disgerminoma' (soon changed to dysgerminoma) for the ovarian tumor that had been described in detail by the French investigator Marcel Chenot 5 years after Chevassu had mentioned the tumor in his paper describing the seminoma. During the Meyer era other significant contributions were made by, among others, Howard C Taylor writing on the borderline tumors and John A Sampson writing on endometriosis and tumors, associated with it. In the second-half of the 20th century major contributions were made by Gunnar Teilum of Denmark and Lars Santesson of Sweden. Dr Teilum delineated the morphologic features of the yolk sac tumor and noted the resemblance of papillary formations within it to the endodermal sinuses of the rat placenta. He also wrote extensively on sex cord tumors in both gonads. At a FIGO meeting in 1961 Dr Santesson played a major role in formulating the first organized classification of the surface epithelialstromal tumors of the ovary and also promoted the endometrioid carcinoma as a special variant of ovarian cancer. In a career spanning over $\mathbf{5 0}$ years, Dr Scully was the architect of the modern classification of ovarian tumors being the driving force behind the influential 1973 World Health Organization classification of them. His many original observations have touched upon virtually all categories of ovarian tumor pathology. His second series fascicle 'Tumors of the Ovaries and Maldeveloped Gonads' utilized the WHO classification and presented a lucid elaboration of his by then vast experience with ovarian tumors. All the above have left a rich legacy which those who follow in their path will be challenged to equal.
\end{abstract}

Modern Pathology (2005) 18, S3-S17. doi:10.1038/modpathol.3800305

Keywords: testis; ovary; history; Maurice Chevassu; Frank J Dixon; Nathan B Friedman

Correspondence: Dr RH Young, MD, Department of Pathology, Massachusetts General Hospital, Warren Building, Fruit Street, Boston, MA 02114, USA.

E-mail: rhyoung@partners.org

Received and accepted 31 August 2004
It is fitting that many of the luminaries within the entire sphere of anatomical pathology have focused so much of their attention on the pathology of the two organs that, along with their accompanying tracts, are responsible for the continuation of the 
human species. In this essay, I highlight the major contributions of these individuals and provide a timeline that indicates how knowledge in this area developed. By doing this I hope appropriate credit is afforded to those to whom we owe so much, although space constraints do not allow for coverage of all meritorious individuals and their contributions. I believe I have emphasized herein those who can truly be considered the most illustrious based on both the number and quality of their contributions. As the focus of this Long Course was mainly on neoplasms my remarks will be largely restricted to observations pertaining to them. I start with the male gonad as the story of its pathology is not quite as rich as that of the female gonad, consideration of which I believe accords a better finale to this contribution.

\section{The testis}

It is always difficult to know exactly where to begin a story of this nature, in other words the point at which anything approaching modern knowledge, or at least hints of it, begin to appear. In a contribution on the history of the surgery of testicular tumors, three eminent British investigators (Drs J Blandy, HF Hope-Stone and AD Dayan) ${ }^{1}$ noted, after exploring the story up to the mid-19th century, 'the modern reader turns with relief to the works of Percival Pott'. ${ }^{2}$ That giant figure who worked at an institution of like stature, Saint Bartholomew's Hospital in London, seems a good starting point. Pott is credited as being 'alone among his contemporaries in recognizing the malignancy of cystic disease', ${ }^{1}$ the latter term being used at that time for tumors of the testis with cysts, mostly pure teratomas or neoplasms with a teratomatous component. This opinion was in contrast to that of another giant, Sir Astley Cooper, who opined that cases of 'cystic disease' were benign. ${ }^{3}$ Nonetheless, as also noted by Blandy and colleagues, Cooper felt that cystic disease and cancer might coexist and advised orchidectomy for such cases. Cooper had a major interest in testicular disease and contributed what may well be the first book of substance on the topic, 'Observations on the Structure and Diseases of the Testis', published in $1830 .^{3}$ The version of this work I have had available for review is an American print of the second London edition, is 247 pages in length and contains 24 plates, many of them with several figures. A 51 page introductory section on the anatomy of the testis is followed by 19 separate chapters on various aspects of benign and malignant disease. Two chapters are devoted entirely to neoplasia, a moderately lengthy one on 'fungoid disease' and a short one on 'scirrhous testis'. Some of the tumors in the first of these two chapters, on the basis of the gross descriptions alone, were likely seminomas. The nature of the cases of 'scirrhous testis' is not readily apparent in that work or when that term is used in another work of that era, Dr Samuel Gross' seminal work 'Elements of Pathological Anatomy'. ${ }^{4}$ However, cases of 'encephaloid' of the testis in the latter read very much like gross descriptions of seminoma and Gross also describes what would doubtless now be considered teratomas or mixed germ cell tumors with a teratomatous component. The common benign lesion, the socalled fibrous pseudotumor, is also clearly described by him.

Thirteen years after Cooper's book another work appeared which Blandy et al note 'remained a classic for half a century'. My reading of that book, by Thomas Blizard Curling ${ }^{5}$ (his uncle was an eminent surgeon, Sir William Blizard), would certainly substantiate that praise. It was translated into French, and French investigators Charles Monod and Octave Terrillon, ${ }^{6}$ in an influential thesis, paid tribute to Curling's book in their introduction. ${ }^{1}$ Curling is, of course, remembered eponymously by the acute duodenal ulcers of patients with severe burns. His book 'A Practical Treatise on the Disease of the Testis and of the Spermatic Cord and Scrotum' runs (in the version available to me, the second American edition) to over 400 pages and has 60 black and white illustrations. ${ }^{5}$ As was common at the time, given the frequency of testicular involvement by syphilis and other infectious diseases, there was greater coverage of inflammatory disease of the testis than neoplasia. Four chapters are devoted to the latter. One entitled 'Carcinoma of the testicle' is divided into 'scirrhous of the testicle,' 'encephaloid cancer of the testicle' (again, likely seminoma), 'melanosis' and carcinoma of the tunica vaginalis. The three other chapters are on cystic disease, fibrous tumor, and a cartilaginous tumor, the latter being a brief presentation of a case that Sir James Paget originally considered an 'enchondromatous tumor', but which was followed by metastases and thus actually was a malignant teratoma.

Apart from the impact of the work of Monod and Terrillon that appeared in $1889,{ }^{6}$ the field was relatively dormant until another French worker, Maurice Chevassu ${ }^{7}$ (Figure 1), an internationally known urologist published his famed thesis of 239 pages in 1906 in which seminoma was clearly described for the first time in a study of 90 cases. Writing almost 40 years after Chevassu's thesis another eminent urologist, $\mathrm{Dr}$ Judson B Gilbert, ${ }^{8}$ noted that Chavassu had 'maintained his interest in these tumors' indicating that Chevassu had a long active career. Chevassu's seminal contribution put the seminoma firmly on the map as arguably the best-known testicular tumor. Although in the ensuing years it was not always given the name elected by Chevassu, séminome, or its English language version, it was highlighted as a distinct neoplasm in most of the notable contributions on testicular tumors. ${ }^{9-13}$ 


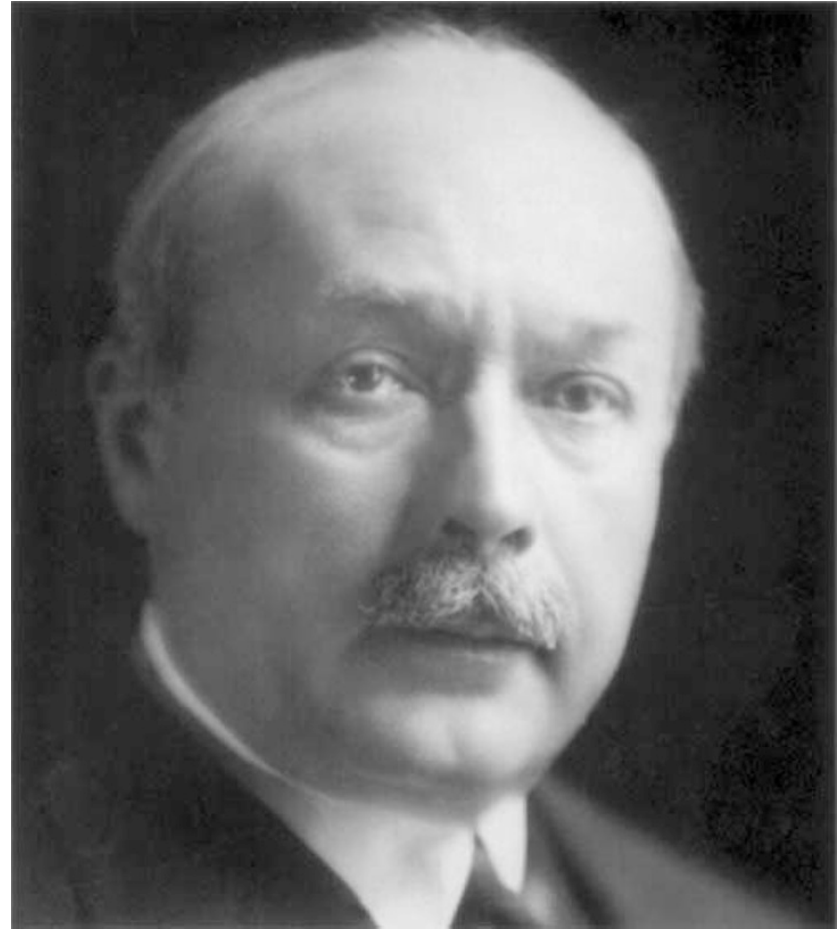

Figure 1 Maurice Chevassu. Famed urologist who described the seminoma.

In 1939, a French histologist, Albert Peyron, ${ }^{14}$ described within a testicular teratoma the enigmatic and picturesque structures which are known in the English language as 'embryoid bodies'. Peyron was remarkably prolific on this topic; in a later contribution on the subject ${ }^{15}$ no less than 17 papers of Peyron are cited! Neoplasms composed predominantly of embryoid bodies, polyembryomas, were subsequently described (in both gonads) and arguably are the most photogenic of all gonadal tumors. ${ }^{16,17}$

In 1946, another French investigator, the eminent Pierre Masson, whose magisterial book ${ }^{18}$ is a gem within the family of general pathology texts, made a major contribution to testicular tumor pathology when he identified from within seminomatous tumors a distinctive neoplasm, the spermatocytic seminoma. ${ }^{19}$ Masson found six cases of this type among approximately 50 testicular tumors of all varieties and commented on never having seen a tumor of this type in association with a teratoma or in the ovary, observations that have stood the test of time. The spermatocytic seminoma is not only an interesting tumor morphologically and clinically, because of its usually benign behavior, but also is a 'proud tumor' in that investigations of it link three of the major figures of 20th century pathology, the aforementioned Dr Masson, Dr Robert E Scully (see below), and Dr Juan Rosai. The spermatocytic seminoma remained largely unknown to most practitioners, despite Masson's efforts, until Dr Scully contributed a second paper on the topic in
$1961^{20}$ outlining in that paper the many differences between this neoplasm and classical seminoma. Seven years later Dr Rosai contributed another major morphologic study and the first ultrastructural examination. ${ }^{21,22} \mathrm{~A}$ notable feature of the first of these two contributions was the manner in which it pointed out the potential for this neoplasm to be misdiagnosed. With commendable diligence $\mathrm{Dr}$ Rosai traveled to the city of origin of one prior study and reviewed the cases; he observed that they did not resemble spermatocytic seminoma as he viewed that neoplasm and subsequently had them reviewed by Dr Lauren V Ackerman and Dr Scully. Dr Rosai credits Dr Scully with the observation that four of the five tumors in the series that was being reviewed were actually malignant lymphomas! The spermatocytic seminoma story had yet another remarkable facet described in the late 1980s when Dr Rosai and Dr Scully pooled, and reported, unusual cases they had seen in consultation in which spermatocytic seminoma was complicated by sarcomatous transformation, a finding that placed a neoplasm that is usually in a good prognostic category in an ominous one. ${ }^{23}$

1946 was a 'good year' for testicular tumor pathology because, in addition to the contribution of Masson, that year saw the publication of one of the seminal studies in this area, 'Tumors of the Testis: A report of 922 cases' by Drs Nathan B Friedman (Figure 2) and Robert A Moore (Figure 3). ${ }^{24}$ Their investigation was of testicular tumors collected at the Armed Forces Institute of Pathology (AFIP) between late 1940 and the middle of 1946. Friedman was on the staff of the AFIP at the time; Moore was chairman of Pathology at Washington University School of Medicine in Saint Louis. As the patients in their series were in the military, the spectrum of ages was different from that of the general population with a resultant skew in the material toward germ cell tumors, even more so than dictated by nature. They classified the tumors into four categories: seminoma, embryonal carcinoma, teratoma, and teratocarcinoma. Chorioepithelioma (choriocarcinoma) was listed under embryonal carcinoma. In addition to laying the foundation for modern terminology, certainly as used in North America, this study is noteworthy for the outstanding illustrations and the lucid and detailed microscopic descriptions. Perhaps the simplest compliment to pay this study is to note than any trainee's knowledge of its contents will serve as an excellent basis for their further study of testicular neoplasia. The only major category of germ cell neoplasia which Friedman and Moore did not appreciate was the yolk sac tumor (endodermal sinus tumor). They do have one illustration that with today's perspective does appear to be that neoplasm although it was interpreted by them as 'atypical reticular pattern' of chorioepithelioma. One of the most important aspects of the paper of Friedman and Moore was their identification of 


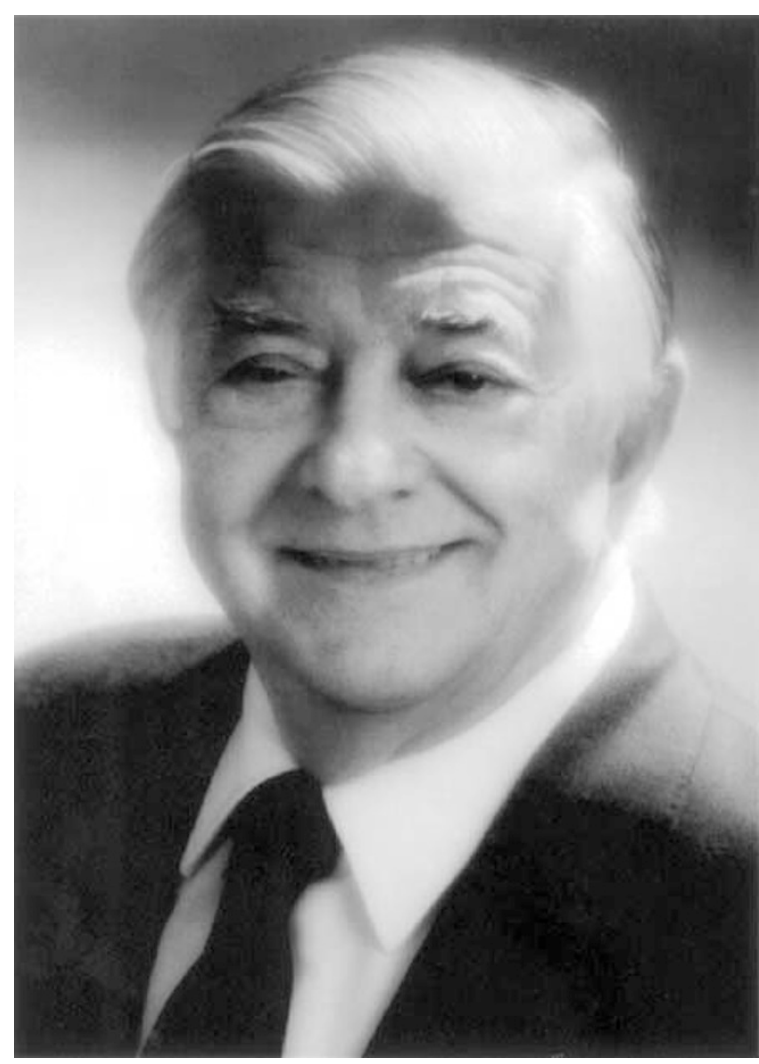

Figure 2 Nathan B Friedman. Coauthor (with Dr Moore) of seminal 1946 paper on testicular tumors.

embryonal carcinoma as a neoplasm distinct from seminoma. It had previously been grouped with seminoma by many workers, including the influential James Ewing. Their observation resulted in embryonal carcinoma being ultimately accepted as a distinctive form of testicular germ cell neoplasia. The AFIP material was utilized again by Dr Frank J Dixon (Figure 4) (at that time at the University of Pittsburgh and later to become an eminent immunobiologist) and Dr Moore, not only in a publication that appeared in Cancer in $1953^{25}$ with more clinical data than the paper of Friedman and Moore, but also in their first series fascicle published in $1952 .{ }^{26}$ The article of Dixon and Moore was preceded by an anonymous one page essay on the history of testicular tumors, ${ }^{27}$ possibly by Dixon or Moore or perhaps the editor of Cancer at that time, Dr Fred W Stewart. The article of Dixon and Moore was followed by Dr Robert E Scully's paper on the unique gonadal lesion, the gonadoblastoma, ${ }^{28}$ making that an illustrious issue of Cancer. The great tradition of testicular pathology at the AFIP has continued and from 1948 until his recent death it was under the leadership of Dr Fathollah K Mostofi (Figure 5) (see below).

In 1948, Dr Scully (Figure 6) made his first of numerous contributions to gonadal pathology. As a resident at the Peter Bent Brigham Hospital in Boston, he undertook a review of all testicular

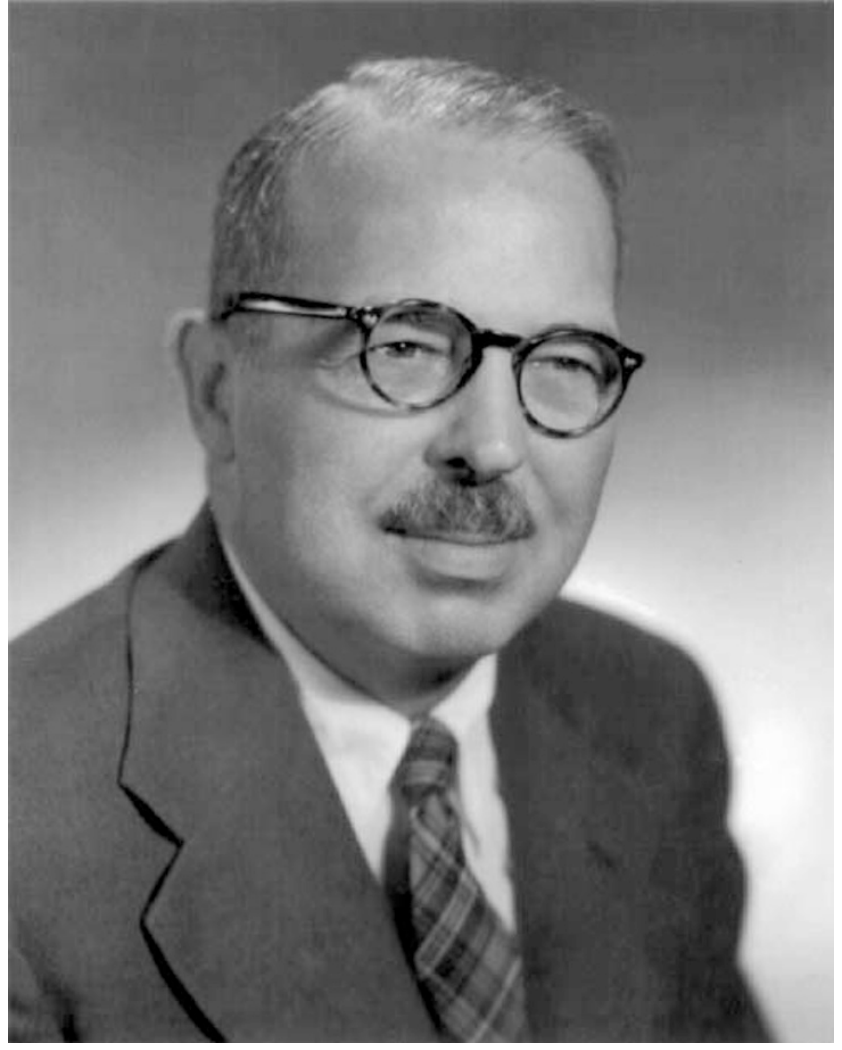

Figure 3 Robert A Moore. Great urologic pathologist and investigator whose contributions with Dr Friedman and Dr Dixon are the foundation of the modern approach to testicular tumor classification

neoplasms encountered there since its founding in 1914. One resultant paper was restricted to germ cell tumors and the other to interstitial (Leydig) cell and miscellaneous neoplasms. ${ }^{29,30}$ That work began a career-long interest in testicular and ovarian pathology. Other noteworthy contributions by him to this area have included, as noted earlier, the first English language paper on spermatocytic seminoma ${ }^{20}$ and descriptions of the large cell calcifying Sertoli cell tumor, ${ }^{31}$ juvenile granulosa cell tumor, ${ }^{32}$ and gonadoblastoma, ${ }^{28}$ the last heralding a lifelong interest in the pathology of intersex as well as the gonads in general. He ultimately reviewed his extended experience with gonadoblastoma many years later in one of the great descriptive clinical and pathologic studies of any area of pathology. ${ }^{33}$ Dr Scully also played a major role in devising the modern classification of premalignant testicular lesions. Although it had been previously noted that atypical germ cells were seen in the seminiferous tubules adjacent to germ cell tumors, the work of NE Skakkebaek and colleagues in Denmark ${ }^{34}$ investigating the testes in patients with infertility, prompted a surge of interest in this area. A classification of precursor lesions was devised in 1980 by a panel of pathologists at an International Symposium on testicular cancer held at the University of Minnesota 


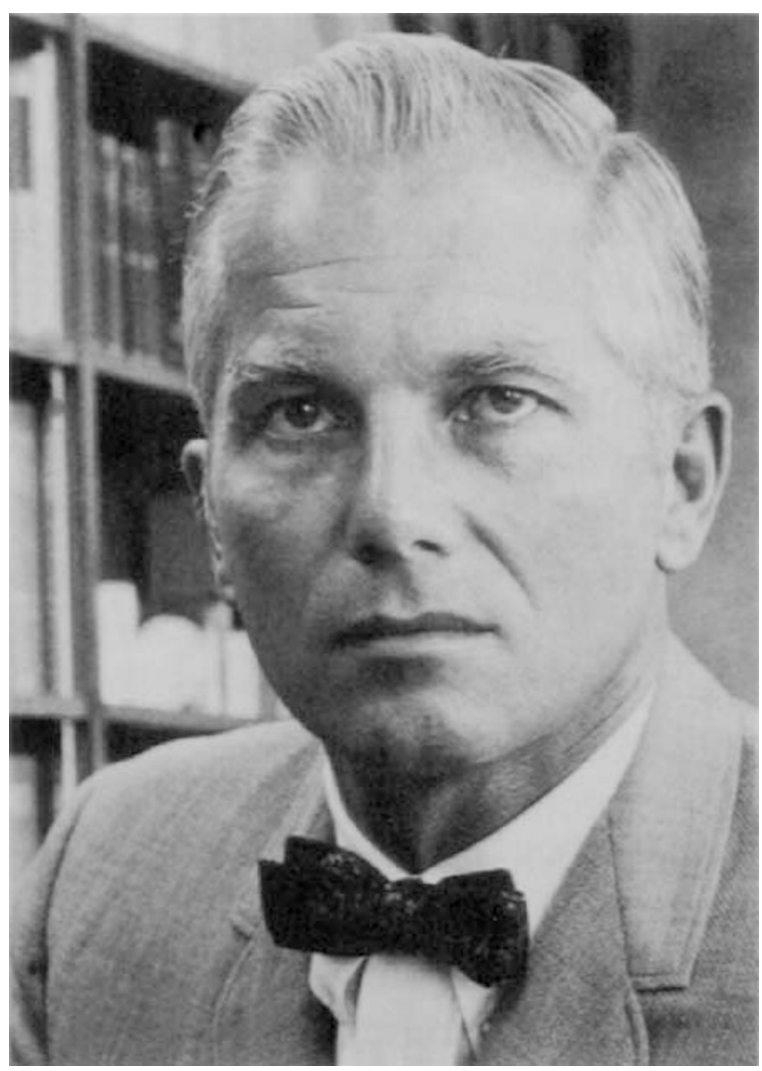

Figure 4 Frank J Dixon. Coauthor (with Dr Moore) of the firstseries Armed Forces Institute of Pathology fascicle on testicular tumors. (Picture courtesy of the New York Academy of Medicine Library).

in June of that year. Dr Juan Rosai organized a oneday symposium on the pathology of testicular germ cell tumors and selected precursor lesions as one of the topics. Dr Rosai has noted elsewhere that the panel 'accepted with slight modification the classification as proposed by Dr RE Scully'35 and a detailed paper based on that meeting was subsequently published, ${ }^{36}$ substituting the term 'intratubular germ cell neoplasia, unclassified' for Skakkebaek's 'carcinoma in situ' because not all these lesions are associated with testicular 'carcinomas'. Later in his career Dr Scully coauthored a book on testicular tumors ${ }^{37}$ and also served, at the request of Dr Rosai (the editor of the third series fascicles) as overseer for the fascicle on the testis which Dr Thomas M Ulbright and colleagues dedicated to Dr Scully. ${ }^{38}$

The saga of the yolk sac tumor is one of the most interesting of all those in gonadal pathology and is inextricably linked with the name of Dr Gunnar Teilum (Figure 7). As his work in the area began with his appreciation that this tumor was present within a group of ovarian neoplasms initially considered of mesonephric derivation, the story of the yolk sac tumor is largely recounted in my survey of the history of ovarian tumors. However, it is pertinent to make a few comments here on

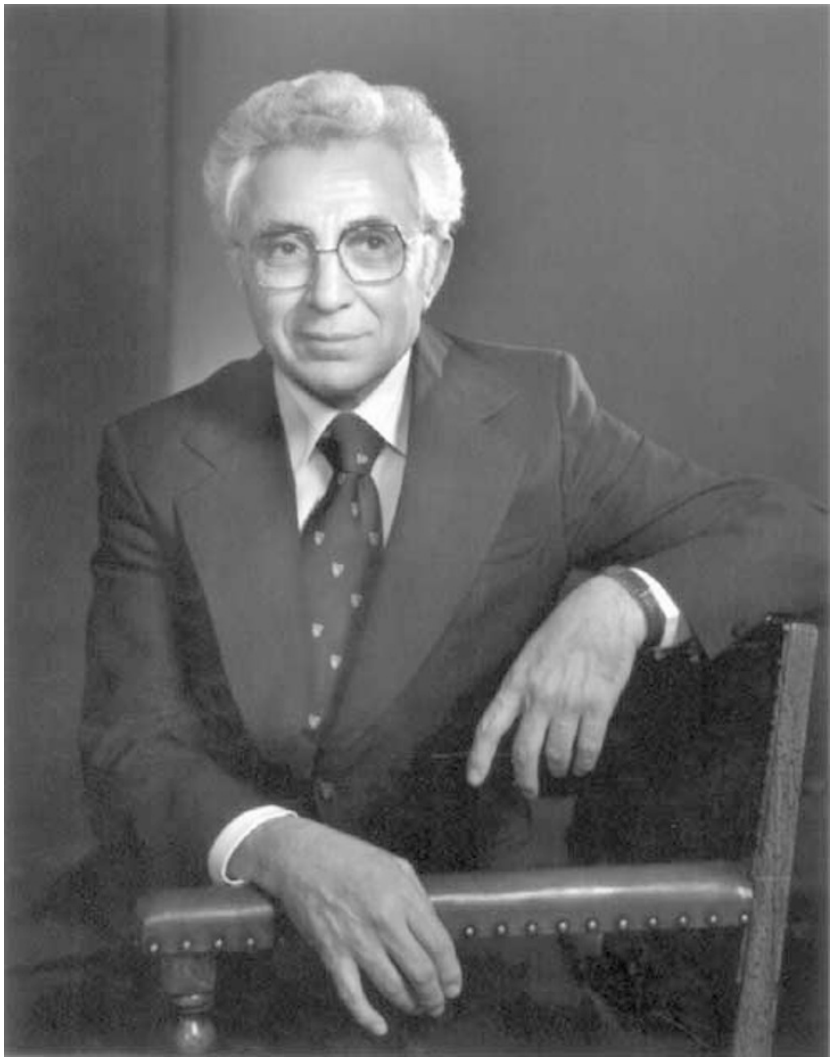

Figure 5 Fathollah K Mostofi. Esteemed genitourinary pathologist, dedicated teacher and great servant of the United States and Canadian Academy of Pathology and International Academy of Pathology.

descriptions of the yolk sac tumor of the testis by others. Retrospectively the first recognizable example of yolk sac tumor of the testis I am aware of is in the British literature in $1910 .{ }^{39}$ That tumor occurred in an infant and that this was a unique tumor of the testis of young boys, particularly when seen in pure form, was highlighted in the 1950s by Magner et al. ${ }^{40}$ Over the ensuing years small series were reported, ${ }^{41}$ but it was not until $1963^{42}$ that the name 'endodermal sinus tumor' was applied to the tumor and specific analogy drawn with the ovarian germ cell tumor described by Teilum, who also described it in the testis largely as a component of mixed germ cell tumors. A few years earlier, original experimental work by Dr G Barry Pierce and Dr FJ Dixon (the earlier contributions of the latter having been previously noted) had shown morphologic similarity between tumors generated in host mice by transplantation of a mouse teratocarcinoma cell line into the murine yolk sac. ${ }^{43,44}$ It was at this time that the term 'yolk sac carcinoma' was first utilized for this histologic appearance, but it was not until 11 years later that the now preferred term of yolk sac tumor was first used in a paper by Dr Pierce with Drs Weldon K Bullock (Director of the California Tumor Tissue Registry for many years) and Dr Robert W Huntington Jr. ${ }^{45}$ 


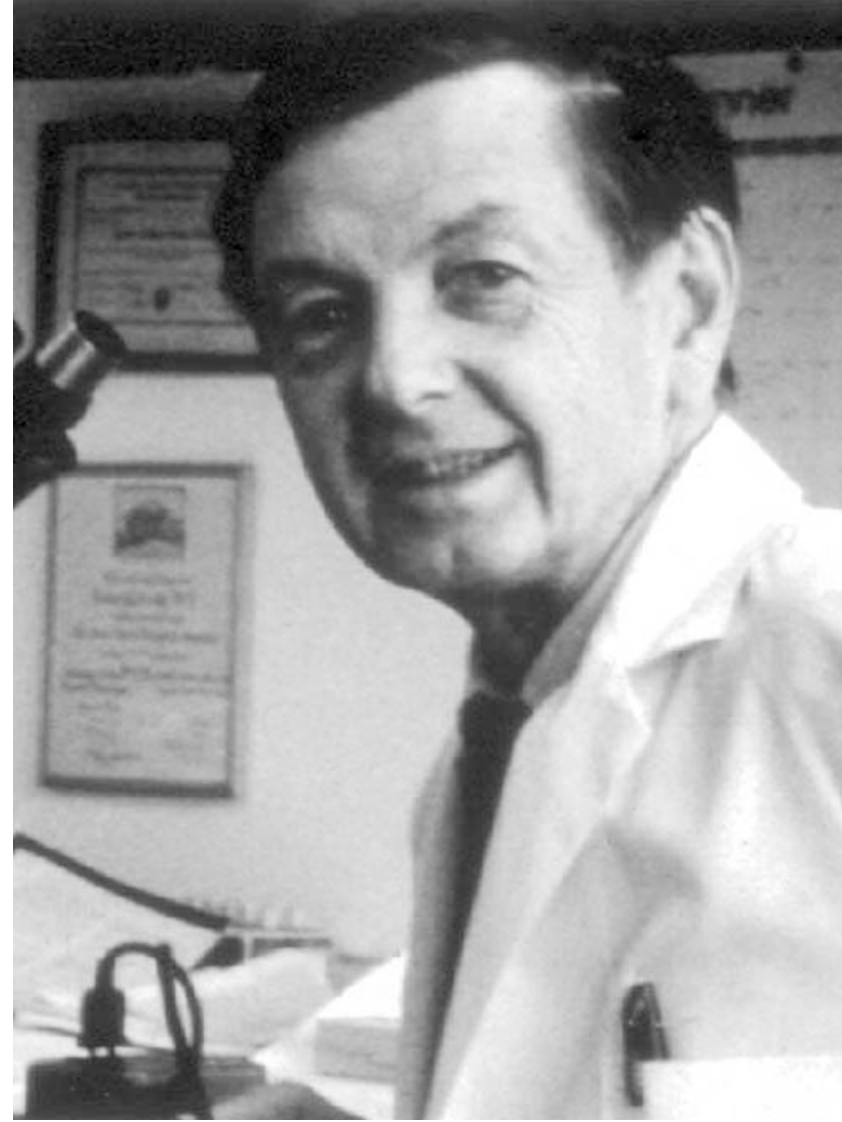

Figure 6 Robert E Scully. Master of gonadal and gynecologic pathology and architect of the modern classification of ovarian tumors.

Teilum was the first to draw significant attention not only to the occurrence of sex cord tumors of the testis but also to their similarity to ovarian neoplasms ${ }^{46-49}$ His last original paper on this topic in $1958^{49}$ put his experience in perspective, and that paper was followed 1 year later by a major paper on this topic from the AFIP group under the leadership of Dr FK Mostofi (Figure 5) ${ }^{50}$ that included the largest experience until that time. The combined observations of Teilum and the AFIP resulted in sex cord tumors of the testis becoming a defined subset of testicular tumors. At almost the same time, Dr Mostofi and colleagues at the AFIP contributed an important paper (with Dr John G Azzopardi as first author) on the remarkable phenomenon, seen only in the testis, of regression of a germ cell tumor, sometimes in the setting of extensive extratesticular spread. ${ }^{51}$

In Great Britain, a somewhat different approach was being used to testicular tumor classification during the time the AFIP group and others were working on the evolving 'North American' classification and Teilum was elucidating the nature of the yolk sac tumor. This culminated in 1964 with the publication of the results of the work of the British Testicular Tumour Panel as a supplement to the

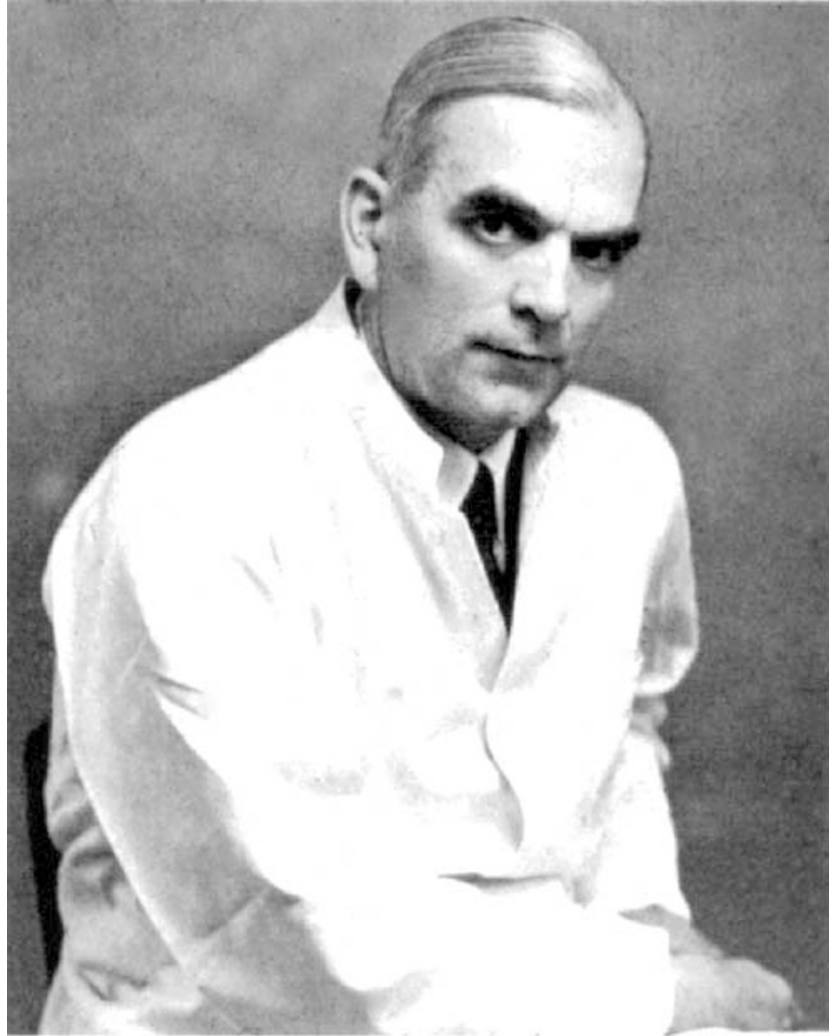

Figure 7 Gunnar Teilum. Great embryologist, anatomist, and pathologist responsible for the delineation of the yolk sac tumor and pioneering studies of gonadal sex cord tumors. (Reproduced with permission from the American Journal of Surgical Pathology).

British Journal of Urology. ${ }^{52}$ That classification had four categories: teratoma differentiated, malignant teratoma intermediate, malignant teratoma anaplastic, and malignant teratoma trophoblastic. Comparison of descriptions and illustrations made it relatively easy to compare this classification with that devised by Friedman and Moore. The British school of testicular tumor pathology under the direction of Dr RCB Pugh produced an outstanding text on the testis in $1976 .{ }^{53}$ Both Dr Pugh's book and the prior supplement to the British Journal of Urology are outstanding contributions that this writer has often had occasion to consult with much benefit.

After the World Health Organization (WHO) classification of ovarian tumors (see below) was almost complete, a companion group headed by $\mathrm{Dr}$ Mostofi was formed in 1972 to devise a similar categorization of testicular tumors. To help promote similar terminology in the two gonads, and because of his known expertise in testicular pathology, Dr Scully served on the group as he had been a major influence in the ovarian group. The classification of testicular tumors, finally published in $1976,{ }^{54}$ was modeled largely on the North American (rather than the British) approach and was similar to that used in 
the second series fascicle authored by Dr Mostofi and Dr EB Price 4 years earlier. ${ }^{55}$ Given the contributions of Dr Mostofi and Dr Scully to gonadal pathology, it is appropriate that in 1971 they jointly presented the well-known prestigious anatomic pathology fall seminar of the American Society of Clinical Pathologists, the session being entitled 'Lesions of the Gonads.'

\section{The ovary}

Early knowledge of the ovary and even the gradual evolution of use of that word to refer to the female gonad have been reviewed by Gruhn, ${ }^{56}$ but it is only with the legendary Morgagni that the story really begins. ${ }^{57,58}$ In his monumental work 'The Seats and Causes of Diseases' he refers to 'vesicles filled with grumous material' and a tumor that was 'evidently bony' suggesting that he had encountered dermoid cysts. ${ }^{58}$ Another giant, Matthew Baillie, also recognized dermoid cysts, having a section in his 'Morbid Anatomy of the Human Body' on 'the ovaria changed into a fatty substance with hair and teeth'. ${ }^{59}$ The early history of ovarian tumors is expertly summarized by Dr CG Ritchie in a wonderful monograph published in $1865 .{ }^{60}$ Among other things Ritchie recounts the publication in 1762 of an English translation of a book by Astruc, consulting physician to the King of France, entitled 'A Treatise on the Diseases of Women.' Ritchie considered that work to be 'the best guide to ovarian pathology in the English language for some period of time.'

The early and middle decades of the 19th century saw contributions by several workers, including three giants best known for contributions in other areas. Dr Thomas Hodgkin made clear reference to what we would now recognize as serous cysts of the ovaries $^{61}$ as did Gross in his previously mentioned book. ${ }^{4}$ Dr Richard Bright (remembered most for his work on renal disease) wrote extensively on abdominal, including ovarian, tumors ${ }^{62}$ and in 1854 another legendary figure, Sir James Paget, ${ }^{63}$ wrote about ovarian cysts in detail, giving credit to the prior contributions of Hodgkin. Paget also described what we would now recognize as the Krukenberg tumor, as elegantly reviewed by Shenoy and Scheithauer ${ }^{64}$ in the more contemporary literature, but he did not appreciate that the ovarian tumors represented spread from extraovarian neoplasms. He did note that there were morphologically similar tumors in other organs.

The mid-19th century saw a significant increase in exposure of surgeons and ultimately pathologists to ovarian tumors because of the advent of surgical exploration of the abdomen and what we now know as oophorectomy, known at that time as ovariotomy. The career of Ephraim McDowell, who blazed the trial in the United States, performing the first ovariotomy in 1809, and pioneering British surgeons such as Spencer Wells and Lawson Tait (both of whom had a major interest in pathology), will not be elaborated on here, as it is largely the domain of surgery, but the interested reader is referred elsewhere. ${ }^{65-69}$

In 1870, Heinrich Waldeyer ${ }^{70}$ (who is of course remembered eponymously for other reasons) wrote a lengthy paper on epithelial ovarian tumors, being among the first to suggest a histogenesis similar to that now widely accepted for the most common form of ovarian cancer. A similar view was espoused by Felix Marchand, ${ }^{71}$ famed for his work on trophoblastic disease. Two years later E Randolph Peaslee authored one of the first books on the ovary to consider pathology, 'Ovarian Tumors: Their Pathology, Diagnosis and Treatment, Especially by Ovariotomy'. ${ }^{72}$ Although the terminology is outdated, credit is still due the writer given the state of knowledge at the time. The last two decades of the 19th century saw two significant British contributions, on the ovary and fallopian tube by Dr Alban Doran $^{73}$ and Dr John Bland Sutton. ${ }^{74}$ The chapter on dermoid cysts in Dr Bland Sutton's book stands the test of time particularly well. In the same period, a number of important contributions were made by Hermann Johannes Pfannenstiel. Writing in the famous German book 'Veit's Handbook of Gynecology' in 1898, he segregated, more clearly than Waldeyer had, the tumors arising from the surface epithelium. ${ }^{75} \mathrm{He}$ was probably the first to introduce the general concept of neoplasms intermediate between those that are unequivocally benign and those that are overtly malignant in his comment on papillary tumors that 'are not really malignant but they have clinical features that stand on the border of malignancy.' He was also likely the first to clearly distinguish between serous and mucinous tumors and wrote on pseudomyxoma peritonei among other topics within the field of ovarian neoplasia. $\mathrm{He}$ certainly deserves a place in the history of ovarian tumor pathology, just as he does within the field of surgery because of his famed incision.

The waning years of the 19th century and early years of the 20th century saw the emergence of the Krukenberg tumor ${ }^{76}$ and the Brenner tumor, ${ }^{77}$ neoplasms that carry Frederick Krukenberg and Fritz Brenner into eternity. Neither neoplasm was interpreted correctly by the individual remembered by the famous eponyms. Krukenberg's work was carried out in the laboratory of Marchand. Krukenberg was only 25 years old when his 35 page paper was published in 1896. That the lesion Krukenberg described as a sarcoma was actually a metastatic carcinoma was recognized by Schlagenhaufer in $1902 .{ }^{78}$ Brenner's work was also carried out at a young age as he was only 30 when his report of 'oophoroma folliculare' was published as a thesis and as a published article the same year (1907) in the German literature. Dr William Ober's recounting of the story of the Brenner tumor is a masterpiece ${ }^{79}$ but this saga is too lengthy to reiterate other than to 


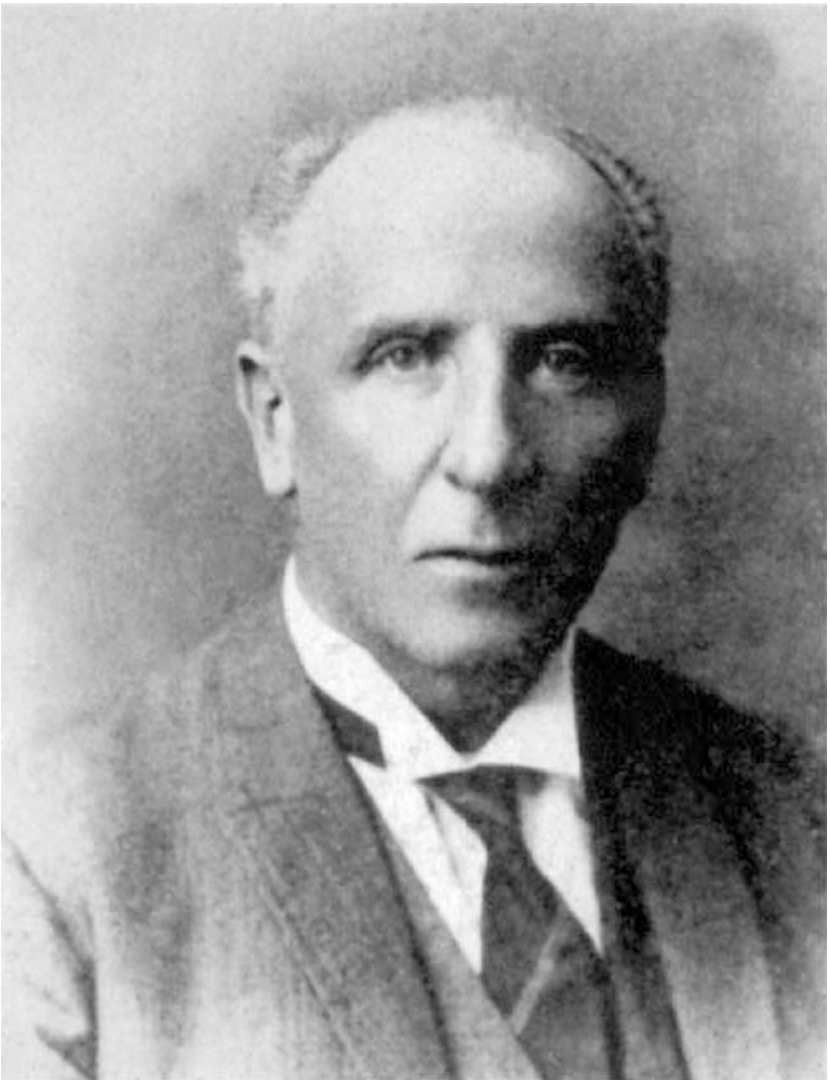

Figure 8 Robert Meyer. His observations represent the first great milestone in ovarian tumor classification. (Reproduced with permission from the American Journal of Obstetrics and Gynecology.)

note that Brenner did not know the eponymous fame he had received, working in relative obscurity in Southern Africa, until found through the efforts of Dr Harold Speert. ${ }^{80}$ Readers unaware of another masterpiece may wish to know of Dr Speert's book, first published in 1958 and recently fortunately expanded and republished, 'Obstetric and Gynecologic Milestones'. ${ }^{81}$ Dr Ober's entertaining essay (with a characteristically flamboyant title and fictitious coauthor!) on Sertoli, Leydig, and Reinke ${ }^{82}$ is also recommended particularly as neoplasms of the cells described by the first two are among the most intriguing within the gonadal family. Mention of the Brenner tumor, which was only clearly distinguished from the granulosa cell tumor many years later by the great German pathologist Robert Meyer (Figure 8), brings us to that individual whose contributions to ovarian tumor pathology place him within the top echelon of all who have had an interest in the area.

Meyer's life and career have recently been reviewed in detail elsewhere ${ }^{83}$ and will be only briefly summarized here. His active career basically spanned the first half of the 20th century and those years for the purposes of this essay are considered 'The Meyer Era.' Apart from his clearly delineating the Brenner tumor as a distinctive neoplasm separate from other tumors with an insular pattern such as the granulosa cell tumor (and instituting the now famous eponymous designation for the former tumor), he elaborated on the various morphologic features of the granulosa cell tumor to a degree greater than had been done before. The history of the granulosa cell tumor was nicely summarized by the eminent British pathologists Drs Harold Fox and Fred Langley ${ }^{84}$ in their book (one of many strengths of which is good consideration of the historical background to the entities they discuss). They and others $^{56}$ credit the great Rokitansky with perhaps first describing what we now know as the granulosa cell tumor, but it was not until 1895 that von Kahlden $^{85}$ described the histologic features of this tumor in detail and the designation 'granulosa cell tumor' was only introduced in 1914 by von Werdt. ${ }^{86}$ In addition to being the subject of many papers, this tumor has been the subject of two monographs, one by Schiller in $1934^{87}$ and another by Varangot in 1937. ${ }^{88}$ The latter writer also contributed to the story of the Brenner tumor by highlighting in 1938, more than Meyer did, the grooved nuclei of the neoplasm. ${ }^{89}$ Meyer introduced the term 'arrhenoblastoma' for the often masculinizing tumor known most widely now as Sertoli-Leydig cell tumor. ${ }^{90}$ Although tumors that can retrospectively be recognized as Sertoli-Leydig cell tumors are present in the older literature, ${ }^{91}$ Meyer's work on these neoplasms brought knowledge of them to a new level. His subclassification of them into well-differentiated, intermediate, and poorly differentiated forms remains the major subcategorization of these tumors that is of practical importance. Another important contribution of Meyer was his coining the term 'disgerminoma' for that famous neoplasm, the change to 'dysgerminoma' being made shortly thereafter. That tumor in the ovary, which one can see examples of in the older literature under the designation 'medullary carcinoma', had been referred to by Chevassu in his famous thesis describing the seminoma ${ }^{7}$ and described in detail as an ovarian neoplasm by another French investigator, Marcel Chenot, in $1911^{92}$ and by Masson ${ }^{93}$ a year later, although both the latter authors used the seminoma designation.

During the Meyer era, others made contributions of note. In 1929, Dr Howard C Taylor expanded on Pfannensteil's concept of tumors intermediate in behavior between benign and malignant. ${ }^{94}$ Three years later he authored another important paper on spontaneous regression of the peritoneal implants of serous ovarian tumors, ${ }^{95}$ and a career-long interest in 'borderline' ovarian tumor is exemplified by the fact that 30 years later he wrote another significant contribution on the topic. ${ }^{96}$ Another investigator of the Meyer era, Dr John Albertson Sampson, 'the father of endometriosis,' drew attention, in 1925, to the association of ovarian endometriosis with carcinoma resembling the common endometrial carcinoma and delineated the nature of ovarian 
endometriotic cysts. ${ }^{97}$ A noteworthy British contribution during the Meyer era was the three-part essay, totalling almost 90 pages, 'The Pathology of Ovarian Tumors' by Dr Wilfred Shaw, published in 1932. ${ }^{98}$ By his phrasing he refers to the potential for the complex invagination of epithelium within the stroma of serous tumors to be misdiagnosed as malignant. He makes a plea, which resonated with me, for the names of tumors not to be changed without good cause even though the original term might be imperfect. His trilogy provides a good sense of knowledge at the time. In 1939, Dr Walter Schiller, an Austrian pathologist who had emigrated to the United States 2 years earlier, ${ }^{99}$ reported a series of ovarian tumors under the designation 'mesonephroma ovarii.' ${ }^{100}$ Although it was subsequently shown by others that the neoplasms were not of mesonephric derivation and that Schiller's paper contained neoplasms we now recognize as yolk sac tumor and others as clear cell carcinoma, his paper is still meritorious given knowledge at the time. Furthermore, Schiller made other important contributions, writing one of the earliest papers on dysgerminoma in $1934 .^{99} \mathrm{He}$ is also credited with pointing out that the granulomatous infiltrate of dysgerminoma, which had previously sometimes been mistaken as representing tuberculosis, was unrelated to that infectious disease. During the Meyer era three commendable books on the ovary written by Drs Samuel Geist, Hans Selye and Gemma Barzilai were published. ${ }^{101-103}$ That time period also saw the birth of another famous eponym related to an ovarian tumor, Meigs' syndrome. ${ }^{104}$ That all is not fair, in as much as eponyms often do not correctly record the first person to describe a disorder, is vividly demonstrated in the case of this eponym, in which many individuals had commented on the manifestations of 'Meigs' syndrome prior to Dr Meigs contributions. ${ }^{105}$ It is, however, not inappropriate that $\mathrm{Dr}$ Joe Vincent Meigs is so immortalized as he was a great clinician with sound knowledge and appreciation of pathology as witnessed by the strength of the latter in his book 'Tumors of the Female Pelvic Organs'. ${ }^{106}$

The story of Schiller's 'mesonephroma ovarii' and the manner in which it was ultimately shown to harbor two separate neoplasms brings us to the contributions of the Danish pathologist, Dr Gunnar Teilum (Figure 7) who was responsible for clarification of the nature of the lesion Schiller described. He is also responsible for most of what we now know about the yolk sac tumor and made other important contributions to gonadal pathology. In 1946, he wrote the first of many English language papers which explored the nature of Schiller's lesion. ${ }^{107}$ Over the ensuing years, ${ }^{108-111}$ culminating in his book published in 1971, ${ }^{112}$ he established the yolk sac tumor (which he referred to as 'endodermal sinus tumor') as a distinctive variant of primitive germ cell tumor and described most of its now wellknown patterns. In the last decade of his life he wrote papers on the localization of alpha-fetoprotein in the tumor cells $\mathrm{s}^{113}$ and relating the morphology of the tumor to alpha-fetoprotein production. ${ }^{114}$ Teilum pointed out that this tumor occurs in both gonads and suggested in one of his earlier papers that it represented a 'gonocytoma'. ${ }^{107}$ In one of the most striking examples of the benefit of comparative morphology, he subsequently noted that the papillary structures of the yolk sac tumor morphologically resembled the endodermal sinuses of the rat placenta after visiting an embryologist in Paris who showed him slides of the rat placenta and coined the term 'endodermal sinus tumor'. ${ }^{109}$ The placental structures in the rat had been designated 'endodermal sinuses' by $M$ Duval in the 19th century and were known to be of yolk sac origin, resulting in Teilum's application of the now famous eponym 'Schiller-Duval bodies' for these structures in yolk sac tumors. In 1959, Dr Teilum finally settled on the name 'endodermal sinus tumor' for 'his' neoplasm, having for a period of time (after the initial gynocytoma terminology) called it 'extraembryonic mesoblastoma'. ${ }^{108}$ With regard to terminology, Dr Teilum seems to have very much preferred his designation of 'endodermal sinus tumor' over yolk sac tumor although he used the latter term as early as $1959,{ }^{109}$ the same year that Pierce and Dixon introduced yolk sac carcinoma into the terminology. In his later writings on the neoplasm, he used the two terms synonymously although it was still clear which of them he preferred. Tributes to Dr Teilum, one of which lists all his papers, are available. ${ }^{115,116}$ In relatively recent years a book on germ cell tumors was dedicated to $\mathrm{Dr}$ Teilum and the famous Schiller-Duval body chosen for the cover illustration. ${ }^{117}$ The final comment on the yolk sac tumor is to note that this remarkable neoplasm is one of the few to have an entire monograph devoted to it and its embryonic counterpart. ${ }^{118}$ The story of the second of the two neoplasms in Schiller's mesonephroma group is told below.

Another Scandinavian pathologist who had a significant impact on ovarian tumor pathology was Dr Lars Santesson (Figure 9) of Sweden. ${ }^{19}$ The International Federation of Gynecology and Obstetrics (FIGO) under the leadership of the pioneering gynecologic oncologist and great collaborator of Dr Santesson, Professor Hans L Kottmeier, was responsible for the organization of a meeting at the Radiumhemmet in Stockholm in August 1961, which produced what many consider the first organized classification of the surface epithelial stromal tumors. Dr Santesson was on that committee along with the following other luminaries: Dr LV Ackerman, Dr G Gricouroff, Dr H Hamperl, Dr AT Hertig, Dr JH Muller, Dr CW Taylor, Dr HC Taylor, and Dr Teilum. At that conference Dr Santesson reported on 660 primary ovarian cancers that had been treated at the Radiumhemmet through 1940 and divided them into the serous, mucinous, and endometrioid groups, this being the first large series 


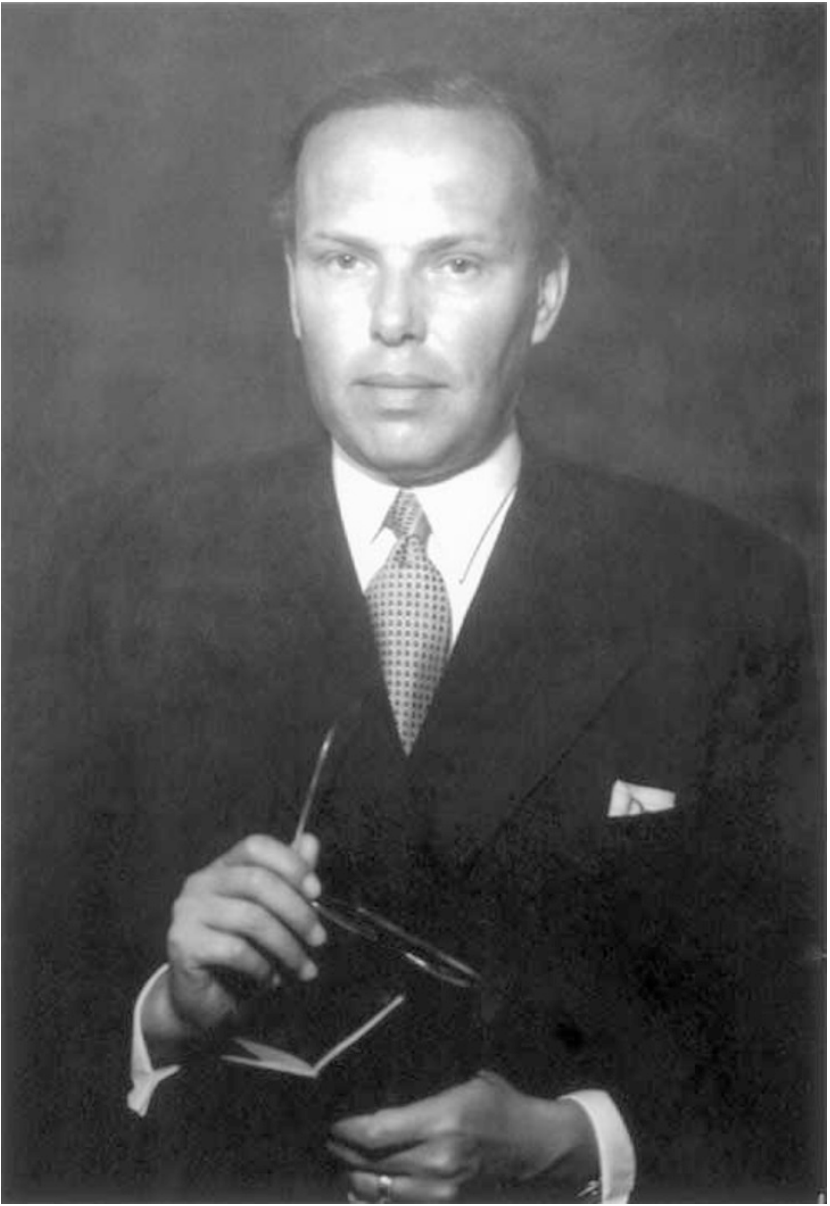

Figure 9 Lars Santesson. Father of the modern classification of the surface epithelial-stromal tumors.

in which endometrioid carcinomas were separately categorized. His observations, as noted elsewhere, ${ }^{120}$ provided the framework for the proposal of that conference that endometrioid tumors be considered a separate entity and that an association with endometriosis, although common, was not required for the diagnosis as it had generally been until then. Santesson and Kottmeier introduced the low malignant potential terminology (a well-known synonym for the borderline tumor group) and Kottmeier, in particular, did much to popularize the category and conservative management of the cases. Kottmeier presented Santesson's pathology on many occasions as Dr Santesson's poor health limited his participation on the national and international scene. In the words of Dr Robert E Scully 'he (Santesson) can be truly called the father of the modern classification of the epithelial tumors of the ovary' (RE Scully, personal communication, January 2004). Santesson also authored important early papers on dysgerminoma ${ }^{121}$ and yolk sac tumor, ${ }^{122}$ using for the latter neoplasm Teilum's preferred name for it at that time, 'mesoblastoma.' The sentence with which he and Kottmeier begin one essay, 'ovarian cancer is not an entity but a group of diseases', ${ }^{123}$ is a truism that some present day researchers should be reminded of. Kottmeier himself wrote extensively ${ }^{124,125}$ and many of his papers were predominantly on pathology, including an important early paper expounding on the borderline concept. ${ }^{124}$ Santesson was also undoubtedly one of those to first appreciate that clear cell carcinoma (or as it was still being called at that time, mesonephroma), was related to the endometrioid carcinoma, his belief being clearly stated by Kottmeier in a review of ovarian tumors in 1965. ${ }^{125}$ The occurrence of clear cells in ovarian adenocarcinomas began to receive attention soon after Schiller's paper ${ }^{126}$ and although the histogenesis was debated, a mesonephric origin was still favored until the late 1950s when De Santo and colleagues indicated a probable origin from Mullerian epithelium. ${ }^{127}$ In the same year that Santesson's opinion on the matter was related (1965), Dr Laman A $\mathrm{Gray}^{128}$ indicated a similar opinion. After 2 years, the matter was put firmly to rest as noted near the end of the next paragraph.

Just as the Meyer era ended with his death in late 1947, the career of Dr Robert E Scully (Figure 6) was beginning. ${ }^{129}$ His early focus from the publishing viewpoint, as previously noted, was testicular tumors and the distinctive lesion of intersex, the gonadoblastoma. ${ }^{28}$ His attention, however, soon turned to the female gonad. A lifelong interest in functioning tumors of the ovary was stimulated by his collaboration with a gynecologist, Dr John McLean Morris, on the book 'Endocrine Pathology of the Ovary,' published in 1958. ${ }^{130}$ A year before the publication of that work, Drs Scully and Morris had drawn attention to the phenomenon whereby tumors that are not normally associated with endocrine manifestations sometimes have such features because of the development of lutein cells in their stroma. ${ }^{131}$ They introduced the term 'ovarian tumors with functioning stroma', a now familiar one. Dr Scully rapidly became known as a consultant for unusual cases in ovarian pathology and developed a remarkable collection which lent itself to many important investigations by him and various collaborators over the years. Although others share the stage with Dr Scully in the author listing of these many papers, all will acknowledge that he was the individual who recognized the various entities, including such now well-known neoplasms as the sclerosing stromal tumor, sex cord tumor with annular tubules, juvenile granulosa cell tumor, strumal carcinoid, small cell carcinoma of hypercalcemic type, and retiform Sertoli-Leydig cell tumor. Appropriately Dr Scully was one of the speakers (on androgenic lesions of the ovary) at the Long Course entitled 'Pathologic Physiology and Anatomy of the Ovary' held in Chicago in April 1961, with the proceedings subsequently published in $1963 .{ }^{132}$ The year 1961 also saw the publication of the first series fascicle on 'Tumors of the ovary and fallopian tube' by Drs Arthur T Hertig and Hazel Gore $^{133}$ who had been responsible for the coverage of estrogenic lesions of the ovary in the Academy Long 


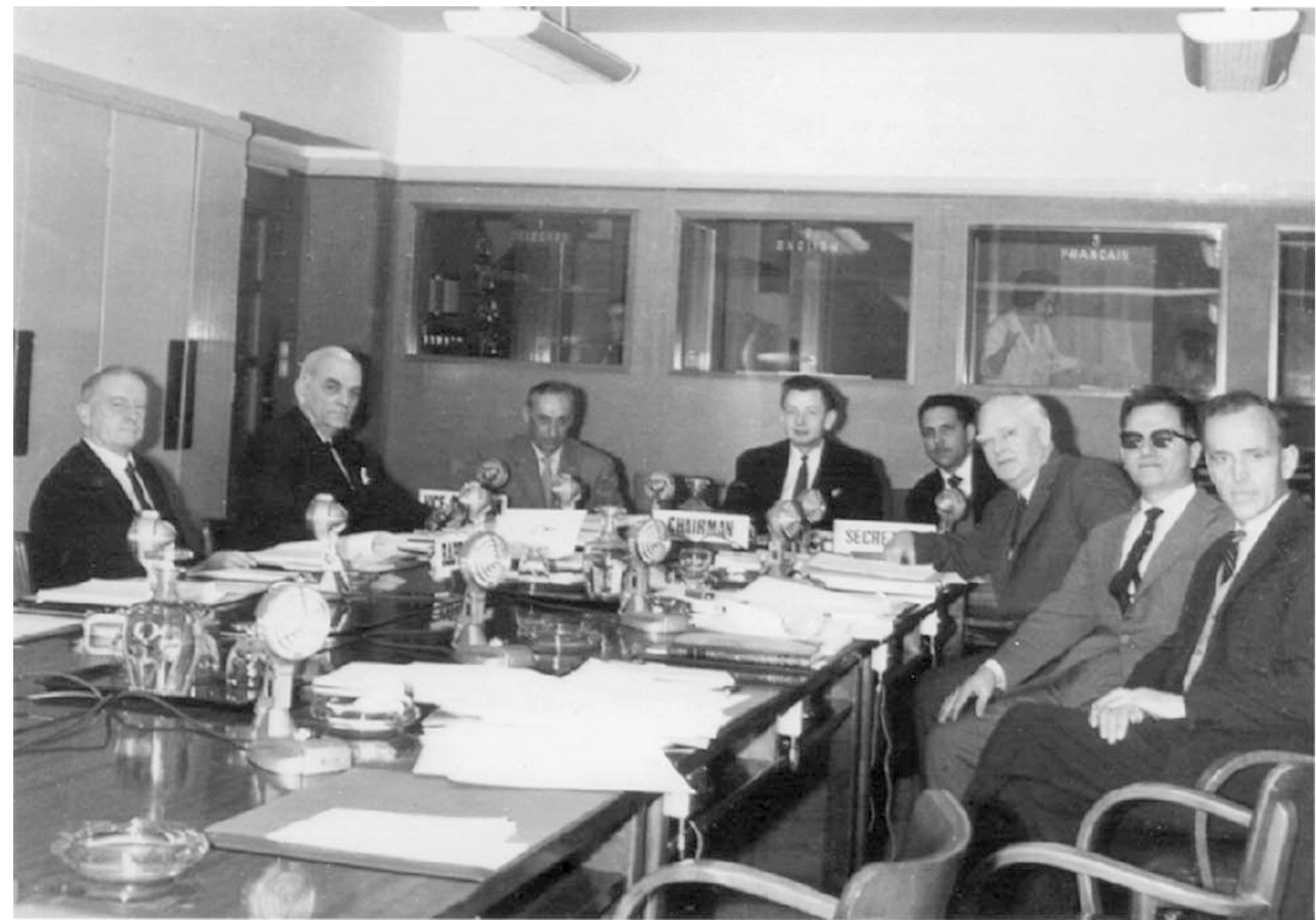

Figure 10 First meeting of World Health Organization (WHO) group on classification of ovarian tumors held in conjunction with FIGO, Geneva, 1963. From left to right: Fred A Langley (Manchester, England), Gunnar Teilum (Copenhagen, Denmark), Georg Gricouroff (Paris, France), Robert E Scully (Boston, USA) Chairman, Humberto Torloni (Sao Paulo, Brazil-Editor of WHO 'Blue' Books at that time), Herwig Hamperl (Bonn, Germany), Antonio Luisi (Sao Paulo, Brazil), Representative of WHO (name not known). Dr SF Serov (Russia) was unable to attend the meeting. Dr L Santesson (Sweden) is missing from this picture but was in attendance.

Course just mentioned. Finally, as alluded to above, in 1967 Dr Scully, in association with Dr John F. Barlow, confirmed the Mullerian histogenesis of clear cell carcinoma by documenting an association with endometriosis and endometrioid carcinoma. ${ }^{134}$ Thus the story of the 'mesonephroma ovarii' ended other than to note that the existence of true mesonephric ovarian neoplasms (Wolffian tumors), sporadically acknowledged by various earlier workers, was firmly established later by $\mathrm{Dr}$ Peter Hughesdon ${ }^{135}$ and Dr Scully. ${ }^{136}$ The academy monograph mentioned above contains, to the best of my knowledge, the first description of the distinctive non-neoplastic lesion, pregnancy luteoma, by $\mathrm{Dr}$ William H Sternberg. ${ }^{137} \mathrm{He}^{138}$ made other important contributions including a major study of ovarian hilus cells and their neoplasms. ${ }^{139}$ That study followed, by seven years, the description of hilus cell tumors ${ }^{140}$ by the French investigator and outstanding member of the 'Masson School', Louis Berger. $^{141}$

1973 saw a major development in the form of the publication of the World Health Organization
(WHO) classification of ovarian tumors. ${ }^{142}$ This was the culmination of work carried out over more than a decade by several major figures in the field of gonadal tumor pathology. The genesis of that undertaking dates back to the previously mentioned 1961 FIGO meeting at which the FIGO Ovarian Cancer Committee devised a classification of the surface epithelial carcinomas of the ovary into five major categories based on cell type, and subdividing each category into three groups, benign, malignant, and an intermediate group designated 'atypical proliferating tumors of low-malignant potential.' Because the WHO (which in 1956-1957 had determined to devise standard classifications of tumors of many sites) was about to embark on a classification of ovarian tumors, Dr H Torloni, editor of the series of WHO tumor classification publications, was contacted by FIGO, which requested a joint meeting of representatives of its committee with those of the WHO group classifying ovarian tumors. At that meeting, held in Geneva in 1963, Dr H Hamperl of Germany was the leader of the FIGO group; Dr L Santesson of Sweden, Dr G Teilum of Denmark, and 
Dr G Gricouroff of France were additional members of the FIGO committee and had been appointed also to the WHO group; and Dr F Langley, Dr AL Luisi, and Dr RE Scully were members of the WHO group (Figure 10). Dr Hamperl and his associates urged the members of the WHO committee to accept with no more than minor modifications the FIGO classification of surface epithelial tumors to avoid the chaos that might result if the classification were to be substantially altered. Dr Scully subsequently served as co-chairman of the further meetings of the WHO group along with Professor SF Serov of Russia. Dr Mikhail Glazunov, another Russian pathologist, who had written a book on ovarian tumors, ${ }^{143}$ had been appointed chairman of the WHO group, but died suddenly before the first meeting was scheduled and was succeeded by his younger associate, Professor Serov, whose primary interest had been bone and soft-tissue tumors. Both Professor Serov and another member of the WHO group, Dr L Przybora of Poland, had been unable to attend the 1963 meeting with the FIGO committee representatives. The first meeting of the WHO ovarian group without FIGO participation was held in St Petersburg in 1965. Material was circulated among the various participants and discussed at a series of meetings that took place between 1967 and 1971. Ultimately, the classification (and selected cases) were reviewed by a second group of pathologists, and the final classification was adopted and published in 1973 as one of the familiar 'blue books' of the International Histologic Classification of tumor publications of that era. ${ }^{142}$

The start of the 1970s saw the publication of an excellent monograph on ovarian tumors by the Czech investigator, Karel Motlik. ${ }^{144}$ The remaining years of that decade saw the publication of two notable books, the previously mentioned 'Tumors of the Ovary' by Drs Fox and Langley, ${ }^{84}$ and the second series fascicle 'Tumors of the Ovary and Maldeveloped Gonads' by Dr Scully. ${ }^{145}$ Although many fine contributions by workers of the current generation have ensued it is perhaps appropriate to end our story at this time with those outstanding books, one from each side of the Atlantic, and leave the 'rest of the story' for another day.

\section{Acknowledgements}

This essay would not have been possible except for the abundant information concerning the history of pathology passed on to me over the years by $\mathrm{Dr}$ Robert E Scully and I am indebted to him for generously sharing his knowledge, numerous papers on history, and some personal communications from individuals mentioned in the essay with me. Essays written for the history series of the International Journal of Gynecological Pathology were a very helpful source of information on several persons mentioned above and thanks are due to the authors of the original essays, Drs Philip B Clement, Gisela Dallenbach-Hellweg, Dietmar Schmidt. Helmuth Pickel, Karl Tamussino, Lawrence Roth, Richard Reed, and the late John Gruhn. Dr Clement, along with Drs Juan Rosai and Thomas M Ulbright, either reviewed this essay for me and provided helpful comments, or provided me beneficial information. Dr Henri Sevestre of Amiens, France kindly provided helpful information on French investigators as did Dr Thomas Seemayer and Dr Gilles Tremblay of Montreal, Canada on the Montreal School. I apologize if I have overlooked any contributions a reader might think worthy of mention but it has been necessary to be selective in this review because of space constraints. Owing to my own linguistic limitations, the essay is largely restricted to coverage of those who have written in the English language and I appreciate the understanding of those whose first language is not English in this regard. Dr Rosemary Tambouret, a colleague at the Massachusetts General Hospital, kindly translated French papers for me and obtained the photograph of Dr Chevassu. Figure 3 was kindly provided by Dr Peter Humphrey of St Louis, USA and Figure 9 by Dr Stefan Cajander, of Uppsala, Sweden. Arlene Shaner of the New York Academy of Medicine Library obtained Figure 4 and was of great assistance.

\section{References}

1 Blandy JP, Hope-Stone HF, Dayan AD. Tumours of the Testicle. Grune and Stratton: New York, 1970.

2 Pott P. The Chirurgical Works of Percival Pott. London, 1779 (cited by Blandy et al).

3 Cooper Sir Astley. Observations on the Structure and Diseases of the Testis. Longman: London, 1830.

4 Gross SD. Elements of Pathological Anatomy, 3rd edn. Blanchard and Lea: Philadelphia, 1857, pp 688-689, 735-736.

5 Curling TB. A Practical Treatise on Diseases of the Testis and of the Spermatic Cord and Scrotum, 2nd edn. Blanchard and Lea: Philadelphia, 1856.

6 Monod C, Terrillon O. Traite des Maladies du testicule et ses annexes. Massonet cit: Paris, 1889.

7 Chevassu M, Thesis. Tumeurs du testicule. Paris, 1906.

8 Gilbert JB. Eponyms in the history of cancer. NY State J Med 1944;44:511-518.

9 Ewing J. Teratoma testis and its derivatives. Surg Gynecol Obstet 1911;12:230-261.

10 Geist SH, Thalhimer W. Histopathology of carcinoma of the testis. Surg Gynecol Obstet 1917;65: $571-581$

11 Tanner CO. Tumors of the testicle with analysis of one hundred original cases. Surg Gynecol Obstet 1922;35: 565-572.

12 Bell FG. Tumours of the testicle: the spermatocytoma group. Br J Surg 1925;13:282-301.

13 Gordon-Taylor G, Till AS. On malignant disease of the testicle, with special reference to neoplasms of the undecended organ. Br J Urol 1938;10:1-45. 
14 Peyron A. Faits nouveaux relatifs à l'origine et à l'histogenèse des embryomes. Bull Ass France Cancer 1939;28:658-681.

15 Marin-Padilla M. Origin, nature and significance of the 'embryoids' of human teratomas. Virch Arch Path Anat 1965;340:105-121.

16 Nicod J-L. Phénomènes de Parthénogenèse dans des tumeurs de l'homme. Bull Soc Vaud de Sc Nat 1945;62:495-505.

17 Simard LC. Polyembryonic embryoma of the ovary of parthenogenic origin. Cancer 1957;10:215-223.

18 Masson P. Tumeurs Humaines, 2nd edn. Libraire Maloine: Paris, 1956 (this edition was translated into English by SD Kobernick and published by Wayne State University Press, Detroit, 1970).

19 Masson P. Étude sur le séminome. Rev Canad Biol 1946;5:361-387.

20 Scully RE. Spermatocytic seminoma of the testis. Cancer 1961;14:788-794.

21 Rosai J, Silber I, Khodadoust K. Spermatocytic seminoma. I. Clinicopathologic study of six cases and review of the literature. Cancer 1969;24:92-102.

22 Rosai J, Khodadoust K, Silber I. Spermatocytic seminoma. II. Ultrastructural study. Cancer 1969;24: 103-116.

23 True LD, Otis CN, Delprado W, et al. Spermatocytic seminoma of testis with sarcomatous transformation. A report of five cases. Am J Surg Pathol 1988;12: 75-82.

24 Friedman NB, Moore RA. Tumors of the testis. A report of 922 cases. Milit Surg 1946;99:573-593.

25 Dixon FJ, Moore RA. Testicular tumors. A clinicopathological study. Cancer 1953;6:427-454.

26 Dixon FJ, Moore RA. Tumors of the male sex organs. Atlas of Tumor Pathology, First series, Armed Forces Institute of Pathology: Washington, DC, 1952.

27 Anonymous. Historical note on testis tumors. Cancer 1953;6:426

28 Scully RE. Gonadoblastoma. A gonadal tumor related to the dysgerminoma (seminoma) and capable of sex hormone production. Cancer 1953;6:455-463.

29 Scully RE, Parham AR. Testicular tumors. I. Seminoma and teratoma. Arch Pathol 1948;45:581-607.

30 Scully RE, Parham AR. Testicular tumors. II. Interstitial cell and miscellaneous neoplasms. Arch Pathol 1948;46:229-242.

31 Proppe KH, Scully RE. Large-cell calcifying Sertoli cell tumor of the testis. A report of ten cases and review of two cases from the literature. Am J Clin Pathol 1980;74:607-619.

32 Lawrence WD, Young RH, Scully RE. Juvenile granulosa cell tumor of the infantile testis. A report of fourteen cases. Am J Surg Pathol 1985;9:87-94.

33 Scully RE. Gonadoblastoma. A review of 74 cases. Cancer 1970;25:1340-1356.

34 Skakkebaek NE. Carcinoma in situ of the testis: frequency and relationship to invasive germ cell tumors in infertile men. Histopathology 1978;2: 157-170.

35 Rosai J. Ackerman's Surgical Pathology, 8th edn. Mosby: St Louis, 1996, pp 1279.

36 Scully RE. Intratubular germ cell neoplasia (carcinoma in situ). What is it and what should be done about it. In: Fraley EE (ed). World Urology Update Series, (Lesson 17) Vol. 1, Continuing Professional Education Center: Princeton, NJ, 1982, pp 1-8.
37 Young RH, Scully RE. Testicular Tumors. ASCP Press: Chicago, 1990.

38 Ulbright TM, Amin MB, Young RH. Tumors of the testis, adnexa, spermatic cord and scrotum. In: Rosai J (ed). Atlas of Tumor Pathology, 3rd Series. Armed Forces Institute of Pathology: Washington, DC, 1999.

39 White CP. A case of carcinoma myxomatodes of the testis occurring in infancy. J Pathol Bacteriol 1910; 14:522-544.

40 Magner D, Campbell JS, Wiglesworth FW. Testicular adenocarcinoma with clear cells, occurring in infancy. Cancer 1956;9:165-175.

41 Teoh TB, Steward JK, Willis RA. The distinctive adenocarcinoma of the infant's testis: an account of 15 cases. J Pathol Bacteriol 1960;80:147-156.

42 Huntington RW, Morgenstern NL, Sargent JA, et al. Germinal tumors exhibiting the endodermal sinus pattern of Teilum in young children. Cancer 1963;16:24-47.

43 Pierce GB, Dixon Jr FJ. Testicular teratomas. I. Demonstration of teratogenesis by metamorphosis of multipotential cells. Cancer 1959;12:573-583.

44 Pierce GB, Dixon Jr FJ. Testicular teratomas. II. Teratocarcinoma as an ascitic tumor. Cancer 1959;12: 584-589.

45 Pierce GB, Bullock WK, Huntington Jr RW. Yolk sac tumors of the testis. Cancer 1970;25:644-658.

46 Teilum G. Homologous tumors in the ovary and testis. Contribution to classification of the gonadal tumors. Acta Obstet Gynec Scand 1944;24:480-503.

47 Teilum G. Arrhenoblastoma-androblastoma. Homologous ovarian and testicular tumors. II. Acta Path Microbiol Scand 1946;23:252-264.

48 Teilum G. Estrogen-producing Sertoli cell tumors (androblastoma tubulare lipoides) of the human testis and ovary. Homologous ovarian and testicular tumors III. J Clin Endocrinol 1949;9:301-318.

49 Teilum G. Classification of testicular and ovarian androblastoma and Sertoli cell tumors. A survey of comparative studies with consideration of histogenesis, endocrinology, and embryological theories. Cancer 1958;11:769-782.

50 Mostofi FK, Theiss EA, Ashley DJB. Tumors of specialized gonadal stroma in human male subjects. Androblastoma, Sertoli cell tumor, granulosa-theca cell tumor of the testis, and gonadal stromal tumor. Cancer 1959;12:944-957.

51 Azzopardi JG, Mostofi FK, Theiss EA. Lesions of testis observed in certain patients with widespread choriocarcinoma and related tumors. Am J Pathol 1961;28:207-225.

52 Collins DH, Pugh RCB. The Pathology of Testicular Tumors. Studies from the Testicular Tumor Registry of the Pathological Society of Great Britain and Ireland in Association with the British Cancer Campaign for Research. Suppl Br J Urol 1964;34:2.

53 Pugh RCB. Pathology of the Testis. Blackwell Scientific Publications: Oxford, 1976.

54 Mostofi FK, Sobin LH. Histological typing of testis tumours. International Histological Classification of Tumours, No. 16. World Health Organization: Geneva, 1976.

55 Mostofi FK, Price Jr EB. Tumors of the Male Genital System. Atlas of Tumor Pathology, 2nd series, Fascicle No. 8. Armed Forces Institute of Pathology: Washington, DC, 1973. 
56 Gruhn JG. A selected historical survey pathology emphasizing neoplasms. In: Roth LM, Czernobilsky B (eds). Tumors and Tumor-like Conditions of the Ovary (Chapter 13). Churchill Livingstone: New York, 1985.

57 Graham H. Eternal Eve. The History of Gynaecology and Obstetrics. Doubleday and Company, Inc.: New York, 1951.

58 Morgagni GB. The Seats and Causes of Diseases (English Translation by Benjamin Alexander). Miller A, Cadell T and Johnson and Payne: London, 1769.

59 Baillie M. The Morbid Anatomy of Some of the Most Important Parts of the Human Body. J Johnson, G Nicol: London, 1793.

60 Ritchie CG. Contributions to Assist the Study of Ovarian Physiology and Pathology. Churchill and Sons: London, 1865.

61 Hodgkin T. On the Anatomical Characters of some Adventitious Structures. Medico-Chirurgical Transactions 1829;XV:265-338.

62 Bright R. Observations on abdominal tumors and intumescence: illustrated by cases of ovarian disease. Guy's Hospital Reports, 1st series 1838;3:179-267.

63 Paget J. Lectures on Surgical Pathology. Lindsay and Blakiston: Philadelphia, 1854.

64 Shenoy BV, Scheithauer BW. Paget's perspectives in pathology. Mayo Clinic Proc 1988;61:184-192.

65 Ridenbaugh MY. The Biography of Ephraim McDowell. M.D. Webster and Co.: New York, 1890.

66 Wells $\mathrm{T}$ Spencer. Diseases of the Ovaries: Their Diagnosis and Treatment. Appleton and Company: New York, 1873.

67 Sheppard JA. Spencer Wells. The Life and Work of a Victorian Surgeon. E \& S Livingstone Limited: Edinburgh, 1965.

68 Tait L. Diseases of The Ovaries. Cornish Brothers: Birmingham, 1886.

69 McKay WJ Stewart, Lawson Tait. His Life and Work. Bailliére Tindall and Cox: London, 1922.

70 Waldeyer H. Die epithelialen Eierstockgeschwülste. Ins besonders die Kystome (The epithelial ovarian tumors, especially the cystic tumors). Arch Gynäkol 1870;1:252-316.

71 Dallenbach-Hellweg G, Schmidt D. History of gynecologic pathology VI. Jacob Felix Marchand. Int J Gynecol Pathol 1999;18:281-287.

72 Peaslee E.Randolph. Ovarian Tumors: Their Pathology, Diagnosis, and Treatment, Especially by Ovariotomy. Appleton \& Company: New York, 1872.

73 Doran AHG. Clinical and pathologic observations on tumours of the ovary, fallopian tube, and broad ligament. Smith, Elder \& Co: London, 1884.

74 Bland-Sutton J. Surgical Diseases of the Ovaries and Fallopian Tubes, Including Tubal Pregnancy. Lea Brothers: Philadelphia, 1891.

75 Pickel H, Tamussino K. History of gynecological pathology. XIV. Herman Johannes Pfannensteil. Int J Gynecol Pathol 2003;22:310-314.

76 Krukenberg F. Ueber das Fibrosarcoma ovarii mucocellulare (carcinomatodes). Arch Gynäkol 1896;50: 287-321.

77 Brenner F. Das Oophoroma folliculare. Frankfurt Z Pathol 1907;1:150.

78 Schlagenhaufer F. Ueber das metastatische Ovarialcarcinom nach Krebs des Magens, Darmes und ander Bauchorgane. Monatsschr Geburtshilfe Gynäkol 1902;15:458-528.
79 Ober WB. History of the Brenner tumor of the ovary. Pathology Annual 1979;14(part 2):107-124.

80 Speert H. Fritz Brenner and Brenner tumors of the ovary. Cancer 1956;9:217.

81 Speert H. Obstetric and Gynecologic Milestones. Parthenon Publishing Group: New York, 1996.

82 Ober WB, Sciagura C. Leydig, Sertoli, and Reinke: three anatomists who were on the ball. Pathol Annu 1981;16(Part 1):1-13.

83 Dallenbach-Hellweg G, Schmidt D. History of gynecological pathology X. Dr Robert Meyer. Int J Gynecol Pathol 2001;20:289-308.

84 Fox H, Langley FA. Tumours of the Ovary. Year Book Medical Publishers: Chicago, 1976.

85 von Kahlden C. Über eine eigentümliche Form des Ovarialcarcinoma. Zentralbl Allg Pathol 1895;6:257.

86 von Werdt F. Über Granulosazelltumoren des Ovariums. Beitr Pathol Anat 1914;59:453-490.

87 Schiller W. Pathologie und Klinik der Granulosazelltumoren. Verlag von Wilhelm Maudrich: Wien, 1934.

88 Varangot J. Les Tumeurs de la Granulosa. Paris, 1937, (cited by Fox and Langley).

89 Varangot J. Les Tumeurs ovariennes du type Brenner: clinique et histogénès. Gynec Obstet 1938;38: $11-22$.

90 Meyer R. Pathology of some special ovarian tumors and their relation to sex characteristics. Am J Obstet Gynecol 1931;22:697-713.

91 Young RH. Sertoli-Leydig cell tumors of the ovary: review with emphasis on historical aspects and unusual variants. Int J Gynecol Pathol 1993;12: 141-147.

92 Chenot M. Contributions à l'étude des épithéliomas primitifs de l'ovaire. Thesis, Paris, 1911.

93 Masson P. Séminomes ovariens. Bull Soc Anat (Paris) 1912;87:402-407.

94 Taylor HC. Malignant and semimalignant tumors of the ovary. Surg Gynecol Obstet 1929;48:204-230.

95 Taylor Jr HC, Alsop WE. Spontaneous regression of peritoneal implantations from ovarian papillary cystadenoma. Am J Cancer 1932;16:1305-1325.

96 Taylor Jr HC. Studies in the clinical and biological evolution of adenocarcinoma of the ovary. J Obstet Gynecol Br Emp 1959;66:827-842.

97 Clement PB. History of gynecological pathology IX. Dr John Albertson Sampson. Int J Gynecol Pathol 2001;20:86-101.

98 Shaw W. The pathology of ovarian tumors. J Obstet Gynecol Br Emp 1932;39:13-30, 234-266, 816-853.

99 Gruhn JG, Roth LM. History of gynecological pathology. V. Dr Walter Schiller. Int J Gynecol Pathol 1998;17:380-386.

100 Schiller W. Mesonephroma ovarii. Am J Cancer 1939; 35:1-21.

101 Geist SH. Ovarian Tumors. Paul B. Hoeber Inc.: New York, 1942.

102 Selye H. Encyclopaedia of Endocrinology. Section IV. Ovary, Vol. VII. Ovarian Tumors. Richardson, Bond and Wright: Montreal, 1946.

103 Barzilai G. Atlas of Ovarian Tumors. Grune and Stratton: New York, 1949.

104 Meigs JV, Cass JW. Fibroma of the ovary with ascites and hydrothorax, with report of seven cases. Am J Obstet Gynecol 1937;33:249-267.

105 Young RH. Meigs' syndrome: Dr Richard Cabot's hidden first American case. Int J Surg Pathol 2000; 8:165-168. 
106 Meigs JV. Tumors of the Female Pelvic Organs. The MacMillan Company: New York, 1934.

107 Teilum G. Gonocytoma. Homologous ovarian and testicular tumors I. With discussion of mesonephroma ovarii Acta Path Microbiol Scand 1946;23:242-251.

108 Teilum G. 'Mesonephroma ovarii' (Schiller). An extraembryonic mesoblastoma of germ cell origin in the ovary and testis. Acta Pathol Microbiol Scand 1950;27:249-261.

109 Teilum G. Endodermal sinus tumours of the ovary and testis. Comparative morphogenesis of the socalled mesonephroma ovarii (Schiller) and extraembryonic (yolk-sac allantoic) structures of the rat's placenta. Cancer 1959;12:1092-1105.

110 Teilum G. Classification of endodermal sinus tumor (mesoblastoma vitellinum) and so-called 'embryonal carcinoma' of the ovary. Acta Pathol Microbiol Scand 1965;64:407-429.

111 Teilum G. Tumors of germinal origin. UICC Monogr Ser 1968;11:58-73.

112 Teilum G. Special tumors of ovary and testis. Comparative Pathology and Histological Identification. Munksgaard: Copenhagen, 1971.

113 Teilum G, Albrechtsen R, Norgaard-Pedersen B. Immunofluorescent localization of alpha-fetoprotein synthesis in endodermal sinus tumor (yolk sac tumor). Acta Pathol Microbiol Scand (A) 1974;82: 586-588.

114 Teilum G, Albrechtsen R, Norgaard-Pedersen B. The histogenetic embryologic basis for reappearance of alpha-fetoprotein in endodermal sinus tumors (yolk sac tumor) and teratomas. Acta Pathol Microbiol Scand (A) 1975;83:80-86.

115 Gormsen H. Professor Gunnar Teilum: 70 years (includes bibliography). Acta Pathol Microbiol Scand Sect A Suppl 1972;233:7-11.

116 Talerman A. Teilum G. Am J Surg Pathol 1981;5: 719-723.

117 Jacobsen GK, Talerman A. Atlas of Germ Cell Tumors. Munksgaard: Copenhagen, 1981.

118 Nogales FF (ed). The Human Yolk Sac and Yolk Sac Tumors. Springer-Verlag: Berlin, 1993.

119 Falkmer S, Cajander S, Young RH, Scully RE. History of Gynecological Pathology XVII. Dr Lars Santesson. Int J Gynecol Pathol (in press).

120 Long ME, Taylor HC. Endometrioid carcinoma of the ovary. Am J Obstet Gynecol 1964;90:936-950.

121 Santesson L. Clinical and pathological survey of ovarian tumours treated at Radiumhemmet. I. Dysgerminomas. Acta Radiol 1947;28:644-668.

122 Santesson L, Marrubini G. Clinical and pathological survey of ovarian embryonal carcinomas, including so-called 'mesonephromas' (Schiller) or 'mesoblastomas' (Teilum) treated at the Radiumhemmet. Acta Obstet Gynec Scandinav 1957;36:399-419.

123 Santesson L, Kottmeier HL. General Classification of Ovarian Tumors. UICC Monograph, No. 11. SpringerVerlag: Berlin, 1968.

124 Kottmeier HL. The classification and treatment of ovarian tumors. Acta Obstet Gynecol Scand 1952;31: 313-363.

125 Kottmeier HL. The diagnosis and treatment of ovarian malignancies. Appl Pathol 1965;37:51-64.

126 Saphir O, Lackner JE. Adenocarcinoma with clear cells (hypernephroid) of the ovary. Surg Gynecol Obstet 1944;79:539-543.

127 DeSanto DA, Bullock WK, Moore FJ. Ovarian cystomas. Arch Surg 1959;78:98-107.

128 Gray LA. Histogenesis of ovarian carcinoma. In: Meigs JV, Sturgis SE (eds). Progress in Gynecology Vol. 4, Grune and Stratton: New York, 1963, pp 465-491.

129 Young RH, Clement PB. An appreciation of Robert E Scully, MD and an introduction to a symposium in his honor on recent advances in gynecologic pathology. Hum Pathol 1991;22:737-746.

130 Morris JMcL, Scully RE. Endocrine Pathology of the Ovary. CV Mosby Company: St Louis, 1958.

131 Scully RE, Morris J McL. Functioning ovarian tumors. In: Meigs J, Sturgis SH (eds). Progress in Gynecology III. Grune and Straton: New York, 1957, pp 31-33.

132 Grady HG, Smith DE (eds). The Ovary. International Academy of Pathology Monograph. Williams and Wilkins Company: Baltimore, 1963.

133 Hertig AT, Gore H. Tumors of the female sex organs Part 3. Tumors of the Ovary and Fallopian Tube. Atlas of Tumor Pathology, Second Series, Armed Forces Institute of Pathology: Washington, DC, 1961.

134 Scully RE, Barlow JF. 'Mesonephroma' of ovary. Tumor of Mullerian nature related to the endometrioid carcinoma. Cancer 1967;20:1405-1417.

135 Hughesdon PE. Ovarian tumours of wolffian or allied nature: their place in ovarian oncology. J Clin Pathol 1982;35:526-535.

136 Young RH, Scully RE. Ovarian tumors of probable wolffian origin. A report of 11 cases. Am J Surg Pathol 1983;7:125-135.

137 Sternberg W. Nonfunctioning ovarian neoplasms. In: Grady HG, Smith DE (eds). International Academy of Pathology Monograph. The Ovary. Williams and Wilkins Company: Baltimore, 1963, pp 234-237.

138 Roth LM, Reed RJ. History of Gynecological Pathology. II. Dr William H. Sternberg. Int J Gynecol Pathol 1997;16:81-85.

139 Sternberg WH. The morphology, androgenic function, hyperplasia and tumors of the human ovarian hilus cells (extraparenchymal Leydig cells). Am J Pathol 1949;25:493-522.

140 Berger L. Tumeur des cellules sympathicotropes de l'ovaire avec virilisation. Rev Canad Biol 1942;1: 539-566.

141 Masson P, Louis Berger. Proceedings and transactions of the Royal Society of Canada Third Series, Vol. XLIII, Ottawa, 1949.

142 Serov SF, Scully RE, Sobin LH. Histologic typing of ovarian tumors In International Histological Classification of Tumors, \#9, World Health Organization: Geneva, 1973.

143 Glazunov MF. Ovarian Tumors. Medgiz: Leningrad, 1961.

144 Motlik K. Ovarian neoplasms Morphology and Classification. Acta Universitatis Carolinae MedicaMonograph XLIV, 1970.

145 Scully RE. Tumors of the Ovary and Maldeveloped Gonads. Atlas of Tumor Pathology, Second Series, Armed Forces Institute of Pathology: Washington, DC, 1979. 